\title{
PERAN BASOFIL DALAM IMUNITAS TERHADAP CACING
}

\author{
Safari Wahyu Jatmiko \\ Departemen Patologi Klinik \\ Fakultas Kedokteran Universitas Muhammadiyah Surakarta \\ Correspondence to: Safari Wahyu Jatmiko \\ Email:Safari.wahyu@ums.ac.id
}

\begin{abstract}
Basophils are polymorphonuclear leukocytes that play an important role in immunity. Basophils can be activated by antibodies and other molecules. Basophils are able to recognize antigens of worms and give some responses. Basophils involvement in immunity againt worms are played by migratingto the worm infected tissue, trigger eosinophilia and eosinophil migration into the tissue, activating mast cells, triggering the formation of AAM, directing Th cell polarization toward Th2 cells, and triggers immunoglobulin class switching to produce $\operatorname{IgE}$.
\end{abstract}

Keywords:Basophil, Helminthiasis

Kecacingan merupakan penyakit yang sampai sekarang masih menjadi permasalahan di berbagai negara. World Health Organization melaporkan lebih dari dua milyar orang terinfeksi cacing dan 300 juta diantaranya dalam kondisi infeksi berat (WHO, 2002). Sementara itu di indonesia, Departemen Kesehatan mempublikasikan bahwa kecacingan merupakan penyakit yang banyak menyerang anak-anak dan sampai tahun 2010 telah dilaporkan 11.969 kasus filariasis di indonesia, bahkan $72 \%$ kabupaten/ kota di Indonesia dinyatakan endemik filariasis (DepKes, 2011).

Tingginya angka kejadian kecacingan dan dampak burukyang dihasilkannya telah mendorong berbagai pihak dengan disiplin ilmu yang berbeda untuk mengadakan penelitian, termasuk di bidang imunologi yang telah memberikan gambaran bagaimana tubuh merespon infeksi cacing.

Ukuran cacing yang jauh lebih besar daripada sel-sel imun menyebabkannya tidak mungkin untuk difagositosis, sehingga tubuh mengembangkan mekanisme tertentu untuk mengatasinya (Karnen \& Iris, 2010). Masuknya cacing ke dalam tubuh akan memicu terbentuknya sel Th2 (Zhu \& Paul, 2008). Setelah terbentuk, sel Th2 merangsang sel B untuk berdeferensiasi menjadi sel plasma yang akan menghasilkan dan mensekresikan IgE. Kemudian, IgE yang terbentuk menempel pada eosinofil dan sel mast melalui ikatan antara IgE dengan FceRI di membran sel. Bila IgE pada sel mast dan eosinofil berikatan dengan cacing maka kedua sel ini akan mengeluarkan berbagai mediator untuk memanggil sel-sel yang lain serta mengeluarkan zat-zat toksik untuk cacing (Abbas \& Lichtman, 2011; MacDonald et al, 2002).

Akhir-akhir ini muncul dugaan adanya peran basofil dalam imunitas terhadap cacing. Hal ini disebabkan karena adanya beberapa bukti ilmiah seperti yang dipaparkan berikut ini. 1. Kenyataan menunjukkan bahwa ada kemiripan fenotipe antara sel mast dengan basofil (Wedemeyer J \& Galli SJ, 2000). 2. Kinetika migrasi antara eosinofil dan basofil sama persis (Iikura, et al 2004). Dari dua fakta ini menunjukkan bahwa basofil mirip dengan eosinofil dan sel mast. Dua sel ini telah diterima sebagai sel yang berperan penting dalam imunitas terhadap cacing. 3. Fakta bahwa IgE juga dapat menempel pada basofil lewat FceRI (MacGlashan, 2007). 4. Hasil eksperimen menunjukkan bahwa pada mencit muda yang mengalami kelambatan munculnya Th2 setalah diinfeksi cacing, dapat diatasi dengan pemberian basofil dari mencit dewasa (Nel et al, 2011). 5. Basofil terakumulasi di jaringan dan mensekresikan IL-4 (Interleukin 
4) setelah diinfeksi dengan cacing (Min B, et al, 2004). 6. Basofil telah teraktifkan pada awal infeksi cacing sebelum munculnya IgE spesifik terhadap cacing (Falcone FH, et al, 2009).

Tulisan ini bertujuan untuk mereview peran basofil dalam imunitas terhadap cacing. Sebab pemahaman yang baik terhadap peran basofil dalam imunitas terhadap cacing diharapkan akan memperbaiki penatalaksanaan kecacingan, pembuatan vaksin dan pencegahan terhadap penyakit lain seperti diabetes tipe I (Bashir MEH, et al, 2002; Saunders, et al 2007)

\section{Basofil}

Basofil merupakan sel lekosit polimorfonuklear yang terdapat dalam darah manusia dan jumlahnya tidak lebih dari $0,5 \%$ (Arock $\mathrm{M}$ et al, 2002; Cadman ET \& Lawrence RA, 2010). Nama basofil diambil dari fakta bahwa sel ini mengikat pewarna yang bersifat basa (Sokol CL \& Medzhitov R, 2010). Pada gambaran darah tepi ia tampak sebagai sel polimorfonuklear dengan granula gelap yang dominan hampir menutupi inti (Ciesla B, 2007).

Basofil diproduksi di sumsum tulang dan memasuki sirkulasi setelah matang. Hal ini berbeda dengan sel mast yang matang di jaringan (Galli SJ, 2000). Umur basofil hanya beberapa hari (Cadman ET \& Lawrence RA, 2010), tetapi ia bisa masuk ke dalam jaringan dengan cara yang mirip dengan eosinofil bila dibutuhkan (Iikura, et al 2004).

Membran sel basofil yang telah matang mengeskpresikan berbagai molekul permukaan yang penting untuk fungsi basofil. Molekulmolekul tersebut adalah: Immunoglobulin receptors, Complement receptors, Homing receptors and related molecules, Receptors untuk cytokines, Receptors untuk chemokines, CD40L, Amphiregulin, Toll-Like Receptor (TLR) 2, TLR 4, TLR 9 dan TLR 10 (Iikura M, 2001; Arock M et al, 2002; Komiya A, et al, 2006; Qi Y, et al, 2010).

Granula basofil mengandung histamin, heparin, leukotrien dan Eosinophil Chemotactic Factor. Bila terkatifasi, basofil mampu mengeluarkan berbagai mediator seperti mediator performed, mediatornewly generated dan sejumlah sitokin. Mediator performed terdiri atas amine, protease netral, proteoglikan, hidrolase asam dan faktor kemotaktik sedangkan mediator newly generated meliputi leukotrien, platelet activating factor. Beberapa sitokin yang dikeluarkan basofil adalah Interleukin 1 (IL-1), 3, 4, 6, Tranforming growth factor beta, tumor necrosing factor alfa, interferon gama dan GMCSF (Granulocyte Macrophage Colony Stimulating Factor) (Karnen \& Iris, 2010; Schneider E et al 2010).

Basofil dapat diaktifkan dengan dua cara, yakni Antibody-Mediated Basophil Activation dan Non-Antibody-Mediated Basophil Activation (Bochner BS, 2000).Antibody-Mediated Basophil Activation adalah aktifasi basofil karena adanya ikatan antara IgE yang melekat pada membran sel (lewat FceRI) dengan antigen (Sullivan BM\&Locksley RM, 2009). Sedangkan NonAntibody-Mediated Basophil Activation adalah aktifasi basofil bukan karena ikatan antara IgE yang melekat pada membran sel dengan antigen, sebagai contoh adalah aktifasi basofil oleh $\mathrm{C} 3 \mathrm{a}$ dan C5a melalui ikatan antara C3a dan C5a dengan C3aR dan C5aR (Stone KD, Prussin C, Metcalfe DD, 2010).

\section{Kemampuan Basofil dalam Mengenali Cacing}

Setiap patogen mempunyai molekul tertentu yang berbeda dengan host sehingga dapat dikenali oleh sistem imun melalui PRR (Pathogen Recognition Receptor). Molekul ini disebut dengan PAMP (Pathogen Associated Molecular Pattern). PAMP pada virus, bakteri dan jamur berikut PRRnya telah diketahui (Janeway CA, \& Medzhitov $\mathrm{R}, 2002)$. Akan tetapi PAMP pada cacing belum diketahui dengan sempurna, sehingga dilakukan banyak penelitian untuk mencari berbagai molekul cacing yang kemungkinan dapat berperan sebagai PAMP (Prithcard DI et al, 1999; Okano M, et al, 2001; van der Kleij D, et al, 2002; Brattig NW, et al, 2004; van den Berg TK, et al 2004).

Telah diketahui bahwa cacing menghasilkan zat-zat yang dikeluarkan dari tubuhnya. Berbagai jenis protein, lipid, glycan dan enzim protease telah diidentifikasi sebagai parasite secretory/ excretory products yang dapat dikenali oleh sistem imun. Selain parasite secretory/excretory products, molekul permukaan cacing seperti chitin juga dapat dikenali oleh sistem imun (Harnett W \& Harnett M, 2006; Perigoue JG, et al, 2008).

Bila terdapat molekul-molekul cacing yang dikenali oleh basofil, maka molekul tersebut akan terikat oleh basofil dengan tata cara tertentu. Berbagai mekanisme pengikatan molekul cacing dengan basofil telah diketahui. Pertama, molekul cacing dapat berikatan dengan basofil melalui IgE 
dengan cara non spesifik antigen, yakni dengan ikatan molekul cacing dengan rantai samping karbohidrat dari IgE (Haisch K, 2001;Aumüller E. et al, 2004; Schramm G et al, 2007) . Pada proses ini molekul cacing berfungsi sebagai super alergen (Falcone FH et al, 2000). Cara kedua adalah dengan ikatan antara protease cacing dengan PAR-Like Receptor (Protease Activated Receptor) (Phillips et al, 2003; Siracusa \& Artis, 2010). Cara ketiga adalah dengan adanya ikatan antara glycanbinding proteins (GBPs) dengan helminth glycans (van Di I \& Cumming RD, 2010). Mekanisme keempat adalah ikatan antara molekul cacing dengan TLR (Brattig NW, 2004). Metode kelima adalah ikatan antara molekul cacing dengan $\operatorname{IgE}$ yang spesifik (Voehringer D, 2009).

Kemampuan basofil mengenal molekul cacing diperlukan untuk mengawali aktifasi basofil. Setelah basofil teraktifkan, maka ia akan mengekspresikan berbagai molekul dengan fungsi tertentu dan mengeluarkan berbagai zat yang diperlukan untuk perlawanan terhadap cacing (Siracusa \& Artis, 2010).

\section{Basofil Bermigrsi ke Tempat yang Terinfeksi Cacing}

Seperti halnya jenis lekosit yang lain, basofil mempunyai kemampuan untuk bermigrasi ke tempat infeksi. Hal ini karena basofil mengekspresikan berbagai molekul permukaan yang dibutuhkan untuk mengadakan migrasi ke tempat infeksi cacing karena pengaruh faktor kemotaktik (Iikura, et al 2004).

Basofil terakumulasi di jaringan dan mensekresikan IL-4 (Interleukin 4) setelah diinfeksi dengan cacing (Min B, et al, 2004). Sementara itu, penelitian yang dilakukan dengan menginfeksi hewan coba dengan cacing memberikan data bahwa basofil terakumulasi di lamina propria, paru dan hati beberapa waktu setelah infeksi (Ohnmacht C \& Voehringer D, 2009).

\section{Basofil sebagai Komponen Innate Immunity yang Terdepan Melawan Cacing}

Penelitian respon imun terhadap cacing pada manusia yang belum pernah terinfeksi menunjukkan bahwa usaha eliminasi cacing sudah terjadi meskipun adaptive immunity belum terbentuk (Falcone FH, et al, 2009). Hal ini menunjukkan bahwa innate immunity merupakan garda terdepan dalam imunitas terhadap cacing.
Basofil sebagai bagian dari innate imunity yang mampu mengenali cacing, kemampuannya untuk bermigrasi ke tempat yang terinfeksi cacing, teraktifkannya sel ini oleh produk cacing serta kemampuannya mengaktifkan sel-sel yang lain baik sel imun maupun non imun (lihat keterangan pada sub bab selanjutnya), menjadikannya kandidat kuat untuk menjadi pemain penting dalam imunitas terhadap cacing.

\section{Peran Basofil dalam Terjadinya Eosinofilia dan Migrasi Eosinofil ke dalam Jaringan}

Eosinofil mempunyai peran penting dalam pertahanan terhadap cacing, karena ia mampu mengeluarkan zat-zat toksik terhadap cacing. Eosinofil diproduksi di dalam sumsum tulang dan dilepaskan ke sirkulasi dan akan memasuki jaringan yang diinvasi oleh cacing. Berbagai kemokin golongan C-C Chemokine telah diketahui bekerja untuk menarik eosinofil ke jaringan, diantaranya adalah Monocyte Chemotactic Protein-1 (MCP1), MCP-3, MCP-5 dan eotaxin (Chensue SW, 2001).

Basofil mempunyai peran dalam terjadinya eosinofilia dan migrasi eosinofil ke dalam jaringan dengan cara memproduksi IL-4, IL-5 dan IL-13 (Phillips C et al, 2003). IL-5 dikenal sebagai sitokin yang mampu meningkatkan produksi eosinofil di dalam sumsum tulang dan pelepasan eosinofil ke dalam sirkulasi serta memperpanjang masa hidup eosinofil (Collin PD et al, 1995; Herbert et al, 2000). IL-4 dan IL-13 merangsang endotel untuk mengekspresikan adhesion molecule yang memudahkan proses masuknya eosinofil ke dalam jaringan serta merangsang endotel untuk memproduksi dan mengekspresikan eotaxin-3 yang merupakan kemotaktik untuk eosinofil(Webb DC et al, 2000; Cuvelier \& Patel, 2001; Teixeira MM et al, 2001; Stone et al, 2010). IL-4 dan IL-13 juga merangsang sel epitel usus untuk memproduksi eotaxin yang merupakan faktor kemotaktik kuat untuk eosinofil (Rothenberg ME, 1999; Ahrens R et al, 2008; Stadnyk AW, 2008; Voehringer, 2009).

Interleukin 4, IL-13 dan TSLP yang dihasilkan basofil mampu mengaktifkan makrofag kearah Alternative activated Macrophage (AAM) (Kreider et al, 2007). Berbagai penelitian menunjukkan bahwa AAM memproduksi Ym1 dan Leukotrien yang bersifat kemotaktik terhadap eosinofil. 


\section{Peran Basofil dalam Aktifasi Sel Mast}

Sel mast telah diketahui mempunyai peranan dalam imunitas terhadap cacing. Akan tetapi untuk mengaktifkan sel mast diperlukan berbagai rangsang, baik yang berasal dari patogen ataupun dari berbagai mediator dari dalam tubuh inang. Pada pasien kecacingan, Interleukin 4 yang diproduksi oleh basofil akan berikatan dengan IL4R pada membran sel mast yang membuat sel mast lebih mudah untuk teraktifkan. Selain itu, IL-4 juga diperlukan untuk pembentukan sel mast (Stone KD, Prussin C, Metcalfe DD, 2010).

\section{Peran Basofil dalam Terbentuknya Alternative Activated Macrophage}

Pada dasarnya makrofag dapat digolongkan menjadi dua golongan bila ditinjau dari sisi cara pengaktifannya. Golongan pertama adalah classic activated Macrophage yang diaktifkan oleh IFN dan alternative activated Macrophage (AAM) yang terutama diaktifkan oleh IL-4 dan IL13 (Gordon S, 2003; Siracusa et al 2008). Pada infeksi cacing, makrofag akan terpolarisasi kearah AAM (Reyes \& Terrazas, 2007; Wang LJ et al, 2008). Polarisasiini terjadikarenaberbagaihal, diantaranyaprodukcacing yang disekresikan (peroxiredoxin), IL-4, IL-13 , IL-21, IL-25, IL-33 dan TSLP (Gordon S, 2003; Donnelly et al, 2005; Kreider et al, 2007; Donnelly et al, 2008; Gordon \& Martinez, 2010).

Basofil yang diketahui merupakan penghasil IL-4, IL-13 dan TSLP berperan penting dalam munculnya AAM (Reece et al 2007; Byers \& Holtzman, 2010). Setelah terbentuk, AAM akan memproduksi berbagai zat yang berguna untuk pertahanan diri terhadap cacing seperti Ym1, RELM, AMCase dan Intelectin. Terbentuknya AAM mengakibatkan direkrutnya eosinofil, menghambat polarisasi sel Th kearah Th1, membantu polarisasi Th kearah Th2, memicu terbentuknya granuloma. Meskipun diketahui bahwa AAM mampu berfusi membentuk Multinucleated Giant Cell (MNG), namun belum ada bukti bahwa terbentuk MNG pada infeksi cacing (Jenkin dan Ellen, 2006).

\section{Peran Basofil dalam Terbentuknya Sel TH2}

Infeksi cacing memicu terpolarisasinya sel

Th0 ke arah sel Th2 dengan menekan terbentuknya sel Th1 (Locksley RM, 1994; Coffman RL \& von der Weid,1997; Zhu \& Paul, 2008). Konsekuensi dari polarisasi ini adalah terbentuknya IL-4, IL5, IL-9, IL-10, IL-13, diikuti dengan terbetuknya immunoglobulin E (IgE), yang akan menempel pada membran sel eosinofil dan sel mast (Garside P et al, 2000; kamal SM \& Khalifa ES, 2006).

Berbagai penelitian menunjukkan bahwa terbentuknya sel Th2 pada pasien kecacingan ditentukan oleh pengenalan antigen cacing yang dilakukan sel dendritik 2 (DC2). Proses pengenalan ini akan mengaktifkan DC2 yang pada gilirannya mengaktifkan sel Th2 (Thomas PG et al, 2003; Kane CM, 2004; Thomas PG et al, 2005). Akan tetapi polarisasi ini tidak terjadi dengan baik bila tidak ada sel basofil. Penelitian menunjukkan bahwa pada binatang yang dibuat sedemikian rupa sehingga mengalami deplesi sel basofil, polarisasi ke arah sel Th2 tidak terjadi meskipun kemampuan presentasi antigen oleh DC tidak hilang. Hal ini menunjukkan bahwa basofil mempunyai peran penting dalam terbentuknya sel Th2 (Perrigoue JG et al 2009; Sokol CL et al, 2009; Yoshimoto T et al, 2009).

Apabila jaringan terinfeksi oleh cacing, maka sel basofil akan bermigrasi ke arah jaringan tersebut (Min B, et al, 2004). Basofil yang direkrut akan teraktifkan oleh beberapa sitokin dan antigen cacing. Setelah teraktifkan, basofil melakukan endositosis antigen cacing dan memprosesnya untuk dipresentasikan ke permukaan membran sel melalui MHC II (Major Histocompatibility Comnplex Class II), dalam hal ini basofil berperan sebagai APC (antigen Presenting Cell) (Perrigoue JG et al 2009; Sokol CL et al, 2009; Yoshimoto $\mathrm{T}$ et al, 2009; Nakanishi K, 2010). Selanjutnya basofil bermigrasi ke draining lymphonodi (dLN) untuk mengadakan kontak sel dengan sel Th0 (Wynn TA, 2009). Kontak antara sel Th0 dengan basofil terjadi melalui ikatan antara TCR (T Cell Receptor) dengan antigen yang dipresentasikan oleh basofil. Setelah berikatan maka sel Th0 akan terpolarisasi ke arah sel Th2 dengan bantuan IL-4 dan TSLP (Thymic Stromal Lymphopoietin) yang dihasilkan oleh basofil (Voehringer D et al, 2006, Oh K et al, 2007;Ramalingam TR et al, 2009).

Selain mempunyai kemampuan sebagai APC, dimungkinkan sel basofil juga mampu merangsang DC untuk mengekspresikan OX40L. Kemampuan ini di dapatkan karena basofil yang teraktifasi akan mensekresikan TSLP dan telah diketahui bahwa TSLP mampu merangsang DC 
untuk mengekspresikan OX40L dan menghambat terbentuknya IL-12. OX40L akan berikatan dengan OX40 pada membran sel Th0 sehingga memicu polarisasi ke arah sel Th2 (Finkelman FD, 2009).

Polarisasi sel Th0 ke arah Th2 pada pasien kecacingan terjadi dengan adanya kontak antara DC2 dan basofil dengan Th0. Hipotesis yang diajukan adalah banyaknya sel yang terlibat dalam terbentuknya sel Th2 memastikan munculnya respon Th2 (Mikhak Z \& Luster AD, 2009)

\section{Peran Basofil dalam Immunoglobulin Class Switching}

Respon imun humoral biasa diakhiri dengan adanya Immunoglobulin Class Swithcing untuk menghasilkan respon imun yang lebih baik, karena mempertahankan spesifisitas terhadap antigen namun memberikan respon imun yang berbeda. Pada awalnya sel B hanya membentuk IgM dan IgD namun setelah terjadi respon imun adaptif maka sel B akan mensekresikan antibodi yang disesuaikan dengan jenis antigen yang masuk, sehingga sel B mungkin akan menghasilkan IgG, IgA ataupun IgE. Pada kasus kecacingan, Immunoglobulin Class Swithcing terjadi dengan terbentuknya IgE (Abbas \& Lichtman, 2011).

Immunoglobulin Class Swithcing terjadi karena adanya dua rangsangan penting. Rangsangan pertama oleh sitokin IL-4 dan atau IL-13, sedangkan rangsangan kedua adalah ikatan antara CD40 pada sel B dengan CD40L (Kashiwada M et al, 2010, Zhang, 2003).

Pada dasarnya Immunoglobulin Class Swithcing dapat digolongkan menjadi dua, yakni Immunoglobulin Class Swithcing T cell Dependent dan $T$ cell Independent (Poole JA et al 2005).Kedua cara ini nampaknya terjadi pada respon imun terhadap cacing.

Immunoglobulin Class Swithcing $T$ cell Dependent dipicuolehsitokinIL-4 yang dikeluarkan oleh sel Th2 dan ikatan antara CD40L dari sel Th2 dengan CD40 pada sel B. Pada proses ini, basofil berperan meningkatkan terjadinya Immunoglobulin Class Swithcing dengan memproduksi dan mensekresikan IL-4(McCoy et al, 2006; Schneider E et al 2010)..

Immunoglobulin Class Swithcing $T$ cell Independent pada pasien kecacinganterjadi karena basofil mengeluarkan IL-4 yang merangsang terbentuknya $I \varepsilon$ Germ Line Transcription pada sel B, sedangkan ikatan antara CD40 pada sel B dengan CD40L pada basofil memicu switch recombination karena ikatan antara CD40-CD40L mengaktifkan AID (Activation-induced cytidine deaminase) pada sel B (Zhang et al 2002; Jabara $\&$ Geha, 2005). Hasil akhirnya adalah kemampuan sel B untuk membentuk IgE tanpa bantuan sel T (Schneider E et al 2010).

\section{Kesimpulan}

Peran basofil dalam respon imun akhirakhir ini mulai terkuak. Basofil diketahui berperan dalam berbagai penyakit termasuk pada penyakit kecacingan. Basofil diketahui mampu mengenali cacing sehingga teraktifkan oleh cacing, bermigrasi ke tempat cacing menginfeksi, mengaktifkan sel-sel lain dan memodulasi sistem imun untuk kepentingan eliminasi cacing atau melokalisir cacing.

Meskipun peran basofil pada kecacingan telah banyak diketahui, namun kebanyakan data didapatkan dari binatang percobaan ataupun secara invitro, sehingga idealnya diperlukan penelitian respon basofil terhadap cacing secara invivo untuk memperbaiki pemahaman.

Respon imun terhadap patogen pada umumnya melibatkan berbagai sel, baik sel-sel imun maupun non imun, tak terkecuali respon imun terhadap cacing. Berdasarkan hal ini, maka diperlukan pengintegrasian pengetahuan tentang peran basofil dengan peran sel-sel yang lain.

Pemahaman yang baik berdasarkan data hasil penelitian invivo serta pengetahuan yang integral tentang respon imun terhadap cacing bermanfaat dalam menciptakan strategi untuk pencegahan (vaksinasi) dan penatalaksanaan kecacingan, maupun untuk mencegah, mengobati dan mengurangi derajat penyakit lain.

\section{DAFTAR PUSTAKA}

Ahrens R, Waddell A, Seidu L, Blanchard C, Carey R, Forbes E, Lampinen, Wilson T, Cohen E, Stringer K, Ballard E, Munitz A, Xu H, Lee N, Lee JJ, Rothenberg ME, Denson L, Hogan SP, 2008, Intestinal Macrophage/ Epithelial Cell-Derived CCL11/Eotaxin-1 Mediates Eosinophil Recruitment and Function in Pediatric Ulcerative Colitis, $\mathrm{J}$ Immunol; 181, 7390-9.

Arock, M., Schneider, E., Boissan, M., Tricottet, V., Dy, M., 2002, Differentiation of human basophils: an overview of recent advances 
and pending questions, J. Leukoc. Biol. 71, 557-64

Aumüller E, Schramm G, Gronow A, Brehm K, Gibbs BF, Doenhoff MJ, Haas H, 2004, Echinococcus multilocularis metacestode extract triggers human basophils to release interleukin-4, Parasite Immunol;26, pg 387-95

Bashir MEH, Andersen P, Fuss IJ, Shi HN, NaglerAnderson C, 2002, An Enteric Helminth Infection Protects Against an Allergic Response to Dietary Antigen,J Immunol 169: 3284-92.

Brattig, NW., Bazzocchi, C., Kirschning, CJ., Reiling, N., Büttner, DW., Ceciliani., F., et al, 2004, The Major Surface Protein of Wolbachia Endosymbionts in Filarial Nematodes Elicits Immune Responses through TLR2 and TLR4, J Immunol,173,437-45

Byers DE, Holtzman MJ, 2010, Alternatively Activated Macrophages as Cause or Effect in Airway Disease, Am J Respir Cell Mol Biol; 43. pg $1-4$,

Cadman, E. T., Lawrence, R. A., Granulocytes: effector cells or immunomodulators in the immune response to helminth infection?, Parasite Immunol, 32, 1-19

Ciesla, B., 2007, Hematology in Practice, $1^{\text {st }}$ ed, Philadelphia: FA Davis, pg 129-39

Cuvelier SL, Patel KD, 2001, Shear-dependent Eosinophil Transmigration on Interleukin 4-stimulated Endothelial cells: Role for Endothelium-associated Eotaxin-3, J. Exp. Med.; 194(12), pg 1699-1709

Chensue SW, 2001, Molecular Machination: Chemokine Signals in Host-Pathogen Interaction, Clin Microbiol Rev: 14(4), pg 821-35

Coffman RL, von der Weid T, 1997, Multiple Pathways for the Initiation of $T$ Helper 2 (Th2) Responses, J. Exp. Med: 185;(3), pg 373-5

Collin DA, Jhonson G, Jose PJ, William TJ, 1995, Cooperation Between Interleukin-5 and the Chemokine Eotaxin to Induced Eosinophil Accumulation in Vivo, J Exp Med; 182, pg 1169-74

Departemen Kesehatan Indonesia, 2011, Profil Kesehatan Indonesia 2010, Kementrian Kesehatan Republik Indonesia, Jakarta

Donnelly S, O’Neill SM, Sekiya M, Mulcahy G, Dalton JP, 2005, Thioredoxin Peroxidase Secreted by Fasciola hepatica Induces the Alternative
Activation of Macrophages, Infect Immun; 73(1), pg 166-73

Donnelly S, Stack CM, O’Neill SM, Sayed AA, Williams DL, Dalton JP, 2008, Helminth 2-Cys Peroxiredoxin Drives Th2 Responses Through A Mechanism Involving Alternatively Activated Macrophages,FASEB J; 22, pg 4022-32

Falcone FH, Haas H, Gibbs BF, 2000, The Human Basophil: A New Appreciation of Its Role in Immune Response, Blood; 96 (13), pg 402834

Falcone FH, Telford G, Hooi D, Brown AP, Sebra R, Feary J, Venn A, Britton J, Prithcard DI, 2009, Antigen-Driven Basophil Activation is Indicative of Early Necator Americanus Infection in IgE-seonegative Patiens, J Allergy Clin Immunol: 124, pg 1343-50

Finkelman FD, 2009, Basophils as TH2-inducing APCs: the dog can sing but is it a diva?, Immunol Cell Biol; 87, pg 568-70

Galli, SJ., 2000, Mast cells and basophils, Curr Opin Hematol, 7, 32-9

Garside P, Kennedy MW, Wakelin D, Lawrence CE, 2000, Immunopathology of intestinal helminth infection, Parasit Immunol: 22, pg 605-12

Gordon S, 2003, Alternative Activated Macrophage, Nat Rev Immunol; 3, pg 23-35

Gordon S, Martinez FO, 2010, Alternative Activation of Macrophages: Mechanism and Functions, Immunity; 32, pg 593-604

Haisch K, Schramm G, Falcone Fh, Alexander C, Schlaak M, Haas H, 2001, A glycoprotein from Schistosoma mansoni eggs binds non-antigen-specific immunoglobulin $E$ and releases interleukin-4 from human basophils, Parasite Immunol: 23: 427-34

Harnet W, Harnett M, 2006, Molecular Basis of Worminduced Immunomodulation, Parasite Immunol; 28, pg 535-43

Herbert DR, Lee JJ, Lee NA, Nolan TJ, Schad GA, AbrahamD, 2000, Role of IL-5 in Innate and Adaptive Immunity to Larval Strongyloides stercoralis in Mice, J Immunol; 165, 454451.

Iikura, M., Ebisawa, M., Yamaguchi, M., Tachimoto, H., Ohta, K., Yamamoto, K., Hirai, K., 2004, Transendothelial Migration of Human Basophils, J Immunol, 173, 5189-95

Iikura M, Miyamasu M, Yamaguchi M, Kawasaki H, Matsushima K, Kitaura M, Morita 
Y,Yoshie O,Yamamoto K, Hirai K, 2001, Chemokine receptors in human basophils: inducibleexpression of functional CXCR4, J Leukoc Biol ,70: pg 113-120

Jabara HH, Geha RS, 2005, Jun N-terminal kinase is essential for CD40-mediated IgE class switching in $B$ cells, J Allergy Clin Immunol;115, pg 856-63

Jenkins, SJ., Allen, JE., 2006, Similarity and Diversity inMacrophage Activation byNematodes, Trematodes, and Cestodes, J Biomed Biotechnol, 262609, 1-14

Kamal SM, Khalifa ES, 2006, Immune modulation by helminthic infections: worms and viral infections, Parasit Immunol; 28, pg 483- 96

Kane CM, Cervi L, Sun J, McKee AS, Masek KS, Shapira S, Hunter CA, Pearce EJ, 2004,Helminth Antigens Modulate TLRInitiated Dendritic Cell Activation, J Immunol: 173, pg 7454-61.

Karnen GB, Iris R, 2010, Imunologi Dasar, ed 9, Balai Penerbit FKUI; Jakarta,

Kashiwada, M., Levy, DM., McKeag, L., Murray, K., Schroeder, AJ., Canfield, SM., et al, 2010, IL-4 Induced Transcription Factor NFIL3/ E4BP4 Controls IgE Class Switching, Proc Natl Acad Sci, 107(2), 821-6

Komiya A, Nagase H, Okugawa S, Ota Y, Suzukawa M, Kawakami A, Sekiya T, Mathsusima K, Ohta K, Hirai K, Yamamoto K, Yamaguchi M, 2006, Expression and function of toll-like receptors in human basophils, Int Arch Clin Immunol; 140 Suppl 1, pg 23-7

Kreider K, Anthony RM, Urban JF. Gause WC, 2007, Alternatively activated macrophages in helminth infections, Curr Opin Immunol; 19(4): 448-53.

Locsley RM, 1994, Th2 Cells: a Help for Helminths, J. Exp. Med: 179, pg 1405-7

MacDonald AS, Araujo MI, Pearce EJ, 2002, Immunology of Parasitic Helminth Infection, Infect Immun: 70;(2), pg 427-33

MacGlashan, D W., 2007, Endocytosis, recycling, and degradation of unoccupied FceRI in human basophils, J. Leukoc. Biol. 82, 1003-10

McCoy, KD., Harris, NL., Diener, PD., Hatak, S., Odermatt, B., Hangartner, L., et al, Natural IgE Production in the Absenceof MHC Class II Cognate Help, Immunity 24, 329-39

Mikhak Z, Luster AD, 2009, The Emergency of Basophil As Antigen-presenting Cell in Th2 Inflamatory Responses, J Mol Cell Biol; 1, 69-71
Min, B., Prout, M., Hu-Li, J., Zhu, J., Jankovic, D., Morgan, ES., et al, 2004, Basophils Produce IL-4 and Accumulate in Tissues after Infection with a Th2-inducing Parasite, $J$ Exp Med, 200(4), 507-17

Nakanishi K, 2010, Basophils are potent antigenpresenting cells that selectively induce Th2 cells, Eur J Immunol; 40: pg 1836-42

Nel, HJ., Hams, E., Saunders, SP., Mangan, NE., Smith, P., Atzberger, A., et al, 2011, Impaired Basophil Induction Leads to an Age-Dependent Innate Defect in Type 2 Immunity during Helminth Infection in Mice, J Immunol, 186:4631-9

Oh K, Shen T,Le Gros G,Min B, 2007, Induction of Th2 type immunity in a mouse system reveals a novel immunoregulatory role of basophils, Blood;109, pg 2921-27

Ohnmacht C, Voehringer D, 2009, Basophil effector function and homeostasis during helminth infection, Blood; 113, pg 2816-25

Okano, M., Satoskar, AR., Nishizaki, K., Harn, DA., 2001, Lacto-N-fucopentaose III Found on Schitosoma mansoni EggAntigens Functions as Adjuvant for Proteins by InducingTh2Type Response 1, J Immunol, 167: 442-50

Perrigoue JG, Saenz SA, Siracusa MC, Allenspach EJ, Taylor BC, Giacomin PR, Nair MG, Du Y, Zaph Y, van Rooijen N, Comeau MR, Pearce EJ, Laufer TM, Artis D, 2009, Major histocompatibility complex class IIdependent basophil-CD4+ Tcell interactions promote TH2 cytokine-dependent immunity, Nat Immunol; 10(7), pg 697-705

Phillips C, Coward WR, Pritchard DI, Hewitt CRA, 2003, Basophils express a type 2 cytokine profile on exposure to proteases from helminths and house dust mites, J. Leukoc. Biol: 73: pg 165-71

Poole JA, Matangkasombut P, Rosenwasser LJ, 2005, Targeting the IgE in Allergic and Asthmatic Disease: Review of the $\operatorname{IgE}$ Molecule and Clinical Efficacy, J Allergy Clin Immunol; 115(3), pg S375-83

Prithcard DI, Brown A, Kasper G, McElroy P, Lokas A, Hewitt C, Berry C, Fulkrug R, Beck E, 1999, A Hookworm Allergen Which Strongly Resembles Calreticulin, Parasite Immunol; 21, pg 439-50

Qi Y, Operario DJ, Oberholzer CM, Kobie JJ, Looney RJ, Georas SN, Mossman TR, 2010, Human Basophil Express Amphiregulin in Response to $T$ Cell-derived $I L-3$, J Allergy Clin Immunol; 126, pg1260-6 
Ramalingam TR, Pesce JT, Mentink-Kane MM, Madala S, Cheever AW, Comeau MR, Ziegler SF, Wynn TA, 2009, Regulation of HelminthInduced Th2 Responses by Thymic Stromal Lymphopoietin, J Immnuol; 182, 6452-9

Reece JJ, Siracusa MC, Scott AL, 2007, Innate Immune Responses to Lung-Stage Helminth Infection Induce Alternatively Activated Alveolar Macrophages, Infect. Immun. 2006, 74(9):4970-81

Reyes J1, Terrazas LI, 2007, The divergent roles of alternatively activated macrophages in helminthic infections, Parasite Immunol; 29, pg 609-19

Rothenberg ME, 1999, Eotaxin: An Essensial Mediator of Eosinophil Trafficking into Mucosal Tissue, Am J Respir Cell Mol Biol; 21, pg 291-5

Saunders, KA., Raine, T., Cooke, A., Lawrence, CE.,2007, Inhibition of Autoimmune Type 1 Diabetesby Gastrointestinal Helminth Infection, Infect Immun, 75(1), 397-407

Siracusa MC, Artis D, 2010, Basophil Functions During Type 2 Inflammation: Initiators, Regulators and Effectors, Open Allergy J; 3, pg 46-51

Siracusa MC, Reece JJ, Urban JF, Scott AL, 2008, Dynamics of lung macrophage activation in response to helminth infection, J. Leukoc. Biol. 84: pg 1422-33

Schneider E, Thieblemont N, De Moraes ML, Dy M, 2010, Basophil: New Player in the Cytokine Network, Eur Cytokine Netw; 21(3), pg 14253

Schramm G, Mohrs K, Wodrich M, Doenhoff MJ, Pearce EJ, Haas H, Mohrs M, 2007, Cutting Edge: IPSE/alpha-1, a Glycoprotein from Schistosoma mansoni Eggs, Induces IgEDependent, Antigen-Independent IL-4 Production by Murine Basophils In Vivo, J Immunol; 178, pg 6023-7

Sokol CL, Chu N, Yu S, Nish SA, Laufer TM, Medzhitov R, 2009,Basophils function as antigen-presenting cells for an allergeninduced $T$ helper type 2 response, Nat Immunol; 10(7), pg 713-21

Sokol CL, Medzhitov R, 2010, Emerging functions of basophils in protective and allergic immune responses, Mucosal Immunol, 3(2), 129-137

Stadnyk AW, 2002, Intestinal Epithelial Cells as a Source of Inflammatory Cytokines and Chemokines, Can J Gastroenterol; 16(4),pg 241-6
Stone KD, Prussin C, Metcalfe DD, 2010, IgE, mast cells, basophils, and eosinophils, J Allergy Clin Immunol; 125, S73-80

Sullivan, BM., Locksley, RM., 2009, Basophil: A Nonredundant Cntributor to Host Immunity, Immunity, 9, 12-20

Teixeira MM, Talvani A, Tafuri WL, Lukacs NW, Hellewell PG, 2001, Eosinophil Recruitment Into Site Of Delayed-Type Hypersensitivity Reaction In Mice, J Leukoc Biol; 69, pg 35360

Thomas PG, Carter MR, Atochina O, Da'Dara AA, Piskorska D, McGuire E, Harn DA, 2003, Maturation of Dendritic Cell 2 Phenotype by a Helminth Glycan Uses a Toll-Like Receptor 4-Dependent Mechanism, J Immunol: 171, pg 5837-41

Thomas PG, Carter MR, Da'dara AA, DeSimone TM, Harn DA, 2005, A Helminth Glycan Induces APC Maturation via Alternative $N F-B$ Activation Independent of IBDegradation, $\mathrm{J}$ Immunol; 175, pg 2082-90.

van den Berg, TK., Honing, H., Franke, N., van Remoortere, A., Schiphorst, WECM., FuTong, L.,et al, 2004, LacdiNAc-Glycans Constitute a Parasite Pattern forGalectin-3Mediated Immune Recognition, J Immunol, $173,1902-7$.

van der Kleij, D., Latz, E., Brouwers, JFHM., Kruize, YCM.,Schmitz, M., Kurt-Jones, EA.,et al, 2002, A Novel Host-Parasite Lipid Crosstalk:Schistosomal Lyso-Phosphatidylserine Activates Toll-Like Receptor 2 And Affects Immune Polarization, J Biol Chem, 277(50), 48122-9

van Die I, Cummings RD, 2010, Glycan gimmickry by parasitic helminths: A strategy for modulating the host immune response?,Glycobiology:20(1) pg. 2-12

Voehringer D, 2009, The role of basophils in helminth infection, Trends in Parasitol ;25 (12), pg 551-6

Voehringer D, Reese TA, Huang X, Shinkai K, Locksley RM, 2006, Type 2 immunity is controlled by $I L-4 / I L-13$ expression in hematopoietic non-eosinophil cells of the innate immune system, J Exp Med; 203 (6), pg 1435-46

Wang LJ, Cao Y, Shi HN, 2008, Helminth infections and intestinal inflammation, World $\mathrm{J}$ Gastroenterol; 14 (33), pg 5125-32

Webb DC, McKenzie ANJ, Koskinen AML, Yang M, Mattes J, Foster PS, 2000, Intergarted Signals Between IL-13, IL-4 and IL-5 
Regulates Airways Hyperreactivity, J Immunol; 165, pg 108-13

Wedemeyer, J., Galli, SJ., 2000, Mast cells and basophils in acquired immunity, $\mathrm{Br} \mathrm{Med}$ Bull, 56 (4), 936-55

World Health Organization, 2002, Prevention and Control of Schistosomiasis and SoilTransmitted Helminthiasis, Geneva: WHO

Wynn TA, 2009, Basophils trump dendritic cells as APCs for TH2 responses, Nat Immunol; 10(7), pg 679-81

Yoshimoto T, Yasuda K, Tanaka H, Nakahira M, Imai Y, Fujimori Y, Nakanishi K, 2009,Basophils contribute to TH2-IgE responses in vivo via IL-4 production and presentation of peptide-MHC class II complexes to CD4+T cells, Nat Immunol; 10(7), pg 706-12

Zhang K, 2003, Accesibility Control and Machinery of Immunoglobulin Class Switch Recombination, J Leukoc Biol, 73, 323-32

Zhang K, Zhang L, Zhu D, Bae D, Nel A, Saxon A, 2002, CD40-mediated p38 mitogen-activated protein kinase activation is required for immunoglobulin class switch recombination to IgE, J Allergy Clin Immunol: 110, pg 4218

Zhu J, Paul WE, 2008, CD4 T cells: fates, functions, and faults, Blood: 122, pg 1557-69 